Krzysztof KoźBIAŁ

Uniwersytet Jagielloński, Kraków

\title{
Inicjatywa naddunajska Unii Europejskiej. Nowy plan Tardieu?
}

\footnotetext{
$\mathrm{D}$
} unaj - druga pod względem długości rzeka Europy, przecinająca ją z zachodu na wschód na przestrzeni $2850 \mathrm{~km}$ jest niewątpliwie osią łączącą duży fragment Starego Kontynentu'. Po tzw. rozszerzeniach wschodnich Unii Europejskiej z 2004 i 2007 r. stał się też rzeką łączącą stare i nowe kraje członkowskie Unii. Spaja z nią także kraje dopiero kandydujące do UE bądź będące na drodze do uzyskania statusu kandydata. Z tego też powodu można by dopatrywać się wręcz symbolicznego znaczenia Dunaju. Czy jest to jednak uzasadnione i czy poza symboliką integracyjną można dostrzec coś więcej w przedstawionej w ostatnich latach, i zaakceptowanej przez Brukselę, inicjatywie mającej na celu wzmożenie kooperacji w tym regionie?

Pomysł dotyczący konieczności zintensyfikowania kontaktów państw położonych w zlewisku Dunaju nie jest nowy. Próby zinstytucjonalizowania kooperacji, w sensie gospodarczym, a także politycznym, podejmowano już w okresie między pierwszą i drugą wojną światową. Nie były one udane.

\section{Propozycje współpracy naddunajskiej okresu międzywojennego}

Obszar państw naddunajskich przynajmniej od zakończenia I wojny światowej uchodził za niespokojną część Europy. Rozpad monarchii Habsburgów - spajającej dotąd większość obszaru naddunajskiego spowodował powstanie kilku państw niepodległych zainteresowanym wpły-

1 Popularna Encyklopedia Powszechna. Kontynenty i państwa, Europa, t. II. Wyd. Fogra, Kraków 2000, s. 79. Zlewisko Dunaju zajmuje obszar 817 tys. $\mathrm{km}^{2}$. Rzeka płynie przez 9 krajów: Niemcy, Austrię, Słowację, Węgry, Chorwację, Serbię, Bułgarię, Rumunię i Ukrainę. 
waniem na politykę w regionie. Powstała Czechosłowacja, Austria, Węgry i Jugosławia, poszerzeniu uległy granice Rumunii i w grupie tych 5 krajów rozstrzygały się losy ewentualnej kooperacji naddunajskiej, którą interesowała się również Polska.

$\mathrm{Na}$ forum międzynarodowym przedstawiano propozycje mające skutkować bliższą kooperacją między poszczególnymi państwami regionu, w tym szczególnie w gospodarce. Ówczesne oferty współdziałania nie były pomysłami oddolnymi. $Z$ reguły były to plany przedstawiane przez tzw. mocarstwa europejskie (Francję, Wielką Brytanię, Włochy czy Niemcy), które posiadały swoje określone interesy dotyczące budowania bloków współpracy politycznej. Region naddunajski stanowił miejsce ścierania się wpływów różnych państw.

Pierwszy plan rozszerzenia kooperacji w regionie dunajskim dotyczył tzw. Federacji Naddunajskiej, do której gotowość w listopadzie 1918 r. wyraziła Austria poprzez deklarację Zgromadzenia Narodowego. Koncepcje włączenia Austrii do Niemiec w tym okresie nie doszły do skutku gdyż wyraźnie stały w sprzeczności z postanowieniami powojennego pokoju z Austrią z Saint Germain i traktatu wersalskiego podpisanego z Niemcami ${ }^{2}$.

Pomysł powiązania Wiednia z Berlinem, tym razem w formie unii celnej odżył ponownie w latach 1930-1931. Był on pochodną kryzysu gospodarczego, który dotykał także środkową część kontynentu. Malała produkcja przemysłu, spadała sprzedaż produktów rolnych co dotykało rolnicze kraje regionu. Wielu widziało rozwiązanie kłopotów w ścisłym związaniu się ekonomicznym z Rzeszą w ramach tzw. Grossraumwirtschaft ${ }^{3}$.

W dniu 19 marca 1931 r. uzgodniono ostateczny tekst porozumienia między Berlinem i Wiedniem przewidujący powstanie unii celnej mającej być wstępem do nowego ustalenia stosunków gospodarczych w tej

2 K. Koźbiał, Między Wiedniem a Bernem, Dylematy polityki zagranicznej Liechtensteinu po 1918 roku, w: Z tradycji prawa w Polsce. Uwarunkowania prawne $w$ kulturze fizycznej, pod red. A. Nowakowskiego, M. Drozda, Rzeszów 2010, s. 206. Szerzej na ten temat także: J. Kozeński, Sprawa przyłaczenia Austrii do Niemiec po I wojnie światowej, Poznań 1967. Wyrazem tendencji do połączenia Austrii z Niemcami stało się początkowe przyjęcie przez nowy kraj nazwy Republika Niemiecko-Austriacka (Republik Deutschösterreich).

3 B. Koszel, Niemcy $w$ polityce państw Europy Poludniowo-Wschodniej $w$ latach 1929-1935, w: Niemcy w polityce międzynarodowej 1919-1939, t. II: Lata wielkiego kryzysu gospodarczego, pod red. S. Sierpowskiego, Poznań 1992, s. 311-312. 
części kontynentu. De facto było to jednak posunięcie Republiki Weimarskiej mającej na celu także połączenie polityczne obu organizmów. W momencie upublicznienia tekstu z 19 marca doszło do protestacyjnych not Paryża, Londynu i Pragi niezainteresowanych unią austriacko-niemiecką. Sprawą zajęła się Rada Ligi Narodów, oddając ją pod ostateczny osąd Stałemu Trybunałowi Sprawiedliwości w Hadze. Tenże miał rozstrzygnąć czy wstępne porozumienie Niemiec i Austrii jest zgodne z traktem z St. Germain. Trybunał haski orzekł, że jest ono sprzeczne ze zobowiązaniami międzynarodowymi Wiednia. Do realizacji planu ostatecznie nie dopuszczono. Istotne było stanowisko państw tzw. Małej Ententy (Czechosłowacja, Rumunia, Jugosławia), gdyż nawiązanie takich kontaktów godziłoby w ich interesy gospodarcze. Szczególnie dotyczyło to Czechosłowacji, dla której unia celna austriacko-niemiecka oznaczałaby zamknięcie rynku austriackiego dla czechosłowackich towarów ${ }^{4}$.

Po upadku koncepcji wspomnianej unii przedstawiciele Małej Ententy jesienią 1931 r. wystąpili na forum Ligi Narodów z pomysłem utworzenia ponadnarodowej organizacji gospodarczej - federacji krajów naddunajskich, którą tworzyłyby Czechosłowacja, Rumunia, Jugosławia, a z czasem także Austria, Węgry i Polska. Spotkało się to tym razem z zainteresowaniem Londynu, lecz i w tym przypadku nie doprowadziło to do żadnych konkretów ${ }^{5}$.

Propagatorem idei bliskiej współpracy w Europie Środkowej i w regionie naddunajskim był węgierski emigracyjny publicysta Elemér Hantos. Obecnie jego koncepcje nie są tak znane jak chociażby „Pan-Europa” Richarda Coudenhove-Kalergiego jednak warte są - w skrótowej formie - przypomnienia w kontekście kooperacja regionu naddunajskiego. Kwestie bliższej kooperacji centrum Europy zajmowały go w wielu publikacjach dotyczących spraw ekonomii, polityki czy kultury Europy Środkowej'. Wskazując na niebezpieczeństwo radykalizacji określonych warstw społecznych uznawał za konieczne dążenie do zbliżenia kulturalnego i ekonomicznego narodów żyjących obok siebie od wieków. Był przeciwnikiem

4 T. Kotłowski, Zabiegi Austrii o unię celnq z Niemcami w 1931 roku, w: Niemcy w..., op. cit., s. 293-303; K. Fiedor, Niemieckie plany integracji Europy na tle zachodnioeuropejskich doktryn zjednoczeniowych 1918-1945, Wrocław 1991, s. 186-203.

5 K. Fiedor, op. cit., s. 203.

6 Zob. m.in.: Die Handelspolitik in Mitteleuropa (Jena 1925), Das Kulturproblem in Mitteleeuropa (Stuttgart 1926), Das Donauproblem in der mitteleuropäischen Wirtschaft (Wien 1929), Die Neuordnung des Donauraumes (Berlin-Wien 1935). 
wszelkich barier handlowych i ceł ograniczających możliwości wymiany międzypaństwowej. Zwracał uwagę, że mogą one być zniesione poprzez współpracę polityczną i szukanie wspólnych punktów współpracy ${ }^{7}$.

Na początku lat 30-tych Hantos widział przyszłość obszaru naddunajskiego nie tylko we współpracy kilku krajów położonych nad Dunajem, lecz w ogólnoeuropejskiej unii celnej. Konsolidacja środkowej części kontynentu miała być jednym z etapów tejże unii. Europa bez tego regionu była w pojęciu węgierskiego myśliciela niepełna. Kluczową rolę odgrywał przy tym Dunaj i 3 państwa położone w jego środkowym biegu: Austria, Czechosłowacja i Węgry ${ }^{8}$.

Największą siłę przebicia posiadały mimo to projekty, za którymi kryło się poparcie dyplomatyczne i polityczne najistotniejszych graczy w stosunkach europejskich początku lat 30-tych ubiegłego wieku. Poparcie to nie było jednak gwarancją sukcesu, o czym świadczy projekt przedstawiony przez premiera Francji.

\section{Plan Tardieu i jego następstwa}

Nieustające problemy gospodarcze Austrii zmusiły Paryż do bliższego skupienia się nad problemami także innych państw tego regionu. Jedną z pierwszych osób, które zaproponowały projekt dotyczący konieczności gospodarczego rozwoju krajów Basenu Naddunajskiego był André François-Poncet ${ }^{9}$. Akcentował on, iż niezbędnym warunkiem tego, aby doszło do ekonomicznego ożywienia w tej części kontynentu jest zwiększenie eksportu zboża z regionu, m.in. z Austrii ${ }^{10}$.

Na tym projekcie opierały się z kolei przemyślenia ówczesnego szefa rządu francuskiego André Tardieu ${ }^{11}$, który w marcu 1932 r. przedstawił

7 M. Jeřábek, Za silnou střední Evropu. Středoevropské hnutí mezi Budapeští, Vidni a Brnem v letech 1925-1939, Praha 2008, s. 38-50.

8 Ibidem, s. 143-149.

9 André François-Poncet (1887-1978) był francuskim dyplomatą, politykiem i germanistą. W latach 1931-1938 był ambasadorem Francji w Berlinie, a następnie w okresie 1938-1940 ambasadorem w Rzymie.

10 B. Koszel, Rywalizacja niemiecko-włoska w Europie Środkowej i na Bałkanach w latach 1933-1941, Poznań 1987, s. 77.

11 André Tardieu (1876-1945) był premierem Francji 3-krotnie: od listopada 1929 do lutego 1930 r., od marca do grudnia 1930 r. oraz od lutego do maja 1932 r. Poza tym wielokrotnie stał na czele wielu ministerstw w kilku francuskich gabine- 
plan nazwany od jego nazwiska. Dokument nosił francuski tytuł: Plan constructif d'une reorganisation de l'Europe Centrale ${ }^{12}$. Była to reakcja Paryża na wspomniany projekt unii celnej austriacko-niemieckiej. Projekt koncentrował się głównie na założeniach gospodarczych, a nie politycznych, w związku z czym warto skrótowo przypomnieć go w kontekście obecnej inicjatywy Brukseli.

\section{André Tardieu}

Źródlo: Library of Congress Prints and Photographs Division Washington, D.C. 20540 USA www.lcweb2.1 oc.gov/service/pnp/ggbain/21100/21131r.jpg, OWikimedia Commons

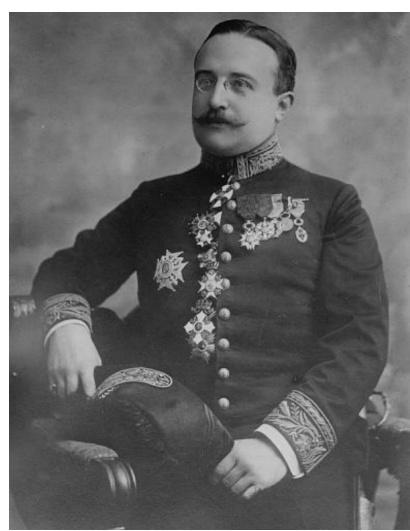

Plan miał być wprowadzany w życie w kilku etapach: poprzez stworzenie porozumienia między Austrią, Węgrami, Czechosłowacją, Rumunią i Jugosławią. W dalszej kolejności do tej grupy mogłyby przystępować inne kraje bałkańskie, a także Polska. W tej swoistej federacji przewage miałyby zatem kraje wówczas rolnicze posiadające nadwyżkę produktów rolnych. Członkowie planu Tardieu ,mieli udzielać sobie wzajemnych preferencji celnych i korzystać z kredytów francuskich"13. Mimo treści gospodarczych Francuzi przedstawili swój plan głównie, jak podkreśla Karol Fiedor, z powodów politycznych ${ }^{14}$. Chodziło o odciągnięcie wymienionych wyżej państw od ewentualnego powiązania ekonomicznego, a w przyszłości być może także politycznego, z Niemcami i związanie ich z Francją. Jednakże same zainteresowane kraje, jak Austria czy Węgry, bardziej oczekiwały od Paryża pomocy finansowej o czym plan premiera Tardieu nie wspominał.

Pomysł nie wszedł w życie bowiem napotkał na dyplomatyczną opozycję przede wszystkim Włoch i Niemiec. Ostatecznie został pogrzebany

tach, był m.in. ministrem spraw zagranicznych, ministrem spraw wewnętrznych i ministrem transportu.

12 H. Batowski, Rok 1938 - dwie agresje hitlerowskie, Poznań 1985, s. 128.

13 K. Fiedor, op. cit., s. 209.

14 Ibidem, s. 208. 
na londyńskiej konferencji mocarstw w początku kwietnia 1932 r. Charakterystyczna była przy tym postawa Wielkiej Brytania, która wyraźnie planu nie wsparła ${ }^{15}$. Zauważalne stały się sprzeczności Francji i Wielkiej Brytania z jednej oraz Włoch i Niemiec z drugiej strony ${ }^{16}$.

Francuzi próbowali jeszcze raz zaangażować się w sprawy środkowoeuropejsko-naddunajskie. W 1935 r. podczas rozmów w Rzymie Włochy i Francja uznały, iż istnieje potrzeba zawarcia tzw. Paktu Dunajskiego gwarantującego niepodległość Austrii i zasadę nieagresji na obszarze odpowiadającym państwom, które miały być objęte wcześniejszym planem Tardieu $^{17}$. Niepowodzenie koncepcji francuskich, głównie planu Tardieu, otwierało drogę do wpływów w tym regionie dla Berlina i Rzymu.

W okresie późniejszym pojawiały się plany de facto wyłącznie polityczne. W lutym 1934 r. doszło do podpisania Porozumienia Bałkańskiego, zwanego też Ententą Bałkańską, między Grecją, Turcją, Jugosławią i Rumunią. Układ ten w zasadzie odrywał Belgrad i Bukareszt od spraw środkowej części kontynentu, kierując je definitywnie ku kwestiom bałkańskim. Nie spodobało się to Rzymowi, któremu przekreślało możliwości oddziaływania na Bałkanach. W konsekwencji Włochy doprowadziły miesiąc później do podpisania tzw. Protokołów Rzymskich między Włochami, Austrią i Węgrami, wiążąc te 3 kraje stosunkami gospodarczymi na zasadzie wzajemnego najwyższego uprzywilejowania. Zawarcie porozumienia było istotne $\mathrm{w}$ sensie polityki Mussoliniego wobec Wiednia i jego braku zgody na nadmierne wpływy hitlerowskie w tym kraju ${ }^{18}$.

\section{Inicjatywa naddunajska Unii Europejskiej}

O potrzebie współpracy w rejonie dorzecza Dunaju wspominała już, na forum publicznym, w 2002 roku minister spraw zagranicznych Republiki Austrii Benita Ferrero-Waldner. Miało to miejsce m.in. podczas konferencji prasowej 8 kwietnia poświęconej austriackiej aktywności zewnętrznej ${ }^{19}$. Inicjatywa wyszła ze strony Rumunii, Komisji Europejskiej,

15 M. Jeřábek, op. cit., s. 170.

${ }_{17}$ Szerzej na temat konferencji zob.: K. Fiedor, op. cit., s. 213-215.

${ }^{17}$ H. Batowski, op. cit., s. 128. Propozycja nie zawierała jednak klauzul gospodarczych.

18 Ibidem, s. 108-111.

19 www.futurum.gov.pl/d_eu/st15/Austria/2002_04_11_Ferrero_Waldner_Bilans_austriackiej_polityki_zagranicznej_ostatnich_dwoch_lat.htm, odczyt 11 grudnia $2010 \mathrm{r}$. 
Paktu Stabilności dla Europy Środkowo-Wschodniej, ale była też gorąco wspierana przez Austrię.

Kilka miesięcy później widziała potrzebę takiej kooperacji w połączeniu z dobiegającym wtedy końca procesem akcesji krajów Europy Środkowej do Unii, który zakończył się rozszerzeniami w 2004 i 2007 roku $^{20}$. Za nie mniej ważne uznała wkład krajów UE, w tym także Austrii - chociażby w osobie dr Erharda Buska - w proces stabilizacyjny na Bałkanach po zakończeniu wojen w byłej Jugosławiii ${ }^{21}$. Propozycja była więc szeroko zakrojona i podobna do obecnej inicjatywy.

Ferrero-Waldner zwracała uwagę, że kraje naddunajskie wykazują daleko idącą różnorodność na tle europejskim: znajdują się wśród nich kraje najbogatsze i najbiedniejsze, członkowie UE, jak i państwa do niej nienależące. Ludność tychże państw reprezentuje różnorodne wyznania, mówi zróżnicowanymi językami należącymi do różnych grup językowych. Zróżnicowanie to może być wprawdzie przyczyną potencjalnych napięć, $\mathrm{z}$ drugiej jednak strony współpraca może i powinna im zapobiec ${ }^{22}$.

W maju 2002 r. podczas wiedeńskiego spotkania ministrów krajów naddunajskich podpisano dokument zatytułowany „Proces Współpracy Naddunajskiej" (Danube Co-operation Process) mający być podstawą intensyfikacji kontaktów i lepszej koordynacji działań regionalnych. Początki dotyczyły takich spraw jak: tworzenie portalu współpracy, ulepszeń dotyczących połączeń transportu drogą wodną i kolejową czy współpraca wiedeńskiej opery z innymi operami funkcjonującymi na analizowanym obszarze. Obszar naddunajski miał zatem stanowić część procesów integracyjnych w Europie i jednocześnie stwarzać perspektywę ewentualnej akcesji do Unii dla krajów bałkańskich leżących w pobliżu Dunaju. Jak podkreślała Ferrero-Waldner ,celem jest gospodarcza i polityczna stabilizacja regionu, co w równej mierze jest w interesie Austrii, jak i Europy"23.

Do pomysłu przedstawionego w 2002 r. wrócono po kilku latach. Nie można jednakże powiedzieć, aby w międzyczasie nie akcentowano po-

20 Der Donau-Kooperationsprozess öffnet den Weg nach Europa, Referat der Bundesministerin für Auswärtige Angelegenheiten Dr. Benita Ferrero-Waldner, Wien am 5. November 2000, s. 2-3. www.cms.euro-info.net/received/_1468_Rede_FW.pdf, odczyt z 5 stycznia 2011 r.

${ }^{21}$ W latach 2002-2008 dr Erhard Busek stał na czele Paktu Stabilności dla Europy Środkowo-Południowej. Zob.: www.stabilitypact.org, odczyt z 20 grudnia 2010 r.

${ }_{22}$ Der Donau-Kooperationsprozess..., op. cit., s. 4.

23 Ibidem, s. 6. 
trzeby współpracy. Czyniono to m.in. na szczeblu lokalnym, rozwijając kooperację między poszczególnymi miastami i regionami położonymi nad drugą co do długości rzeką w Europie. Miały miejsce 4 konferencje miast i regionów połączonych Dunajem: w 2003 r. w Ulm, w 2005 r. w Nowym Sadzie, w 2007 r. w bułgarskim Widyniu oraz w 2009 r. w Budapeszcie. Podczas tej ostatniej, odnosząc się do końcowych deklaracji z poprzednich spotkań, utworzono Radę Naddunajskich Miast i Regionów (Rat der Donaustädte und - regionen), która ma reprezentować sygnatariuszy dokumentu budapesztańskiego wobec instytucji Unii Europejskiej, m.in. wobec Komisji, Parlamentu, Rady UE, Komitetu Regionów czy też Rady Współpracy Regionalnej dla Europy Południowo-Wschodniej. Członkami powstałej Rady Naddunajskiej są przedstawiciele miast i regionów oraz reprezentanci tzw. biur dunajskich. Współpraca w ramach Rady ma przyjąć m.in. formę:

- wsparcia dla licznych inicjatyw dotyczących spotkań młodzieży;

- działań w zakresie kultury;

- kooperacji dotyczącej ochrony środowiska naturalnego (projekty mające na celu poprawę jakości wód);

- wsparcia dla transferu know-how w zakresie ochrony środowiska i współpracy regionalnej;

- pomoc dla nauki i oświaty w regionie;

- tworzenie oferty turystycznej, m.in. ścieżek rowerowych ${ }^{24}$.

Dużą inicjatywą w zakresie projektów mających na celu międzynarodową współpracę wykazuje się też niemieckie miasto Ulm. W 2002 r. powstał m.in. projekt Biuro Dunajskie (donau.büro.ulm $\mathrm{GmbH}$ ), który przeprowadza projekty w dziedzinie polityki, kultury, nauki czy ekologii mające na celu współpracę transgraniczną. Jego powstanie stało się z kolei impulsem do utworzenia sieci 13 kolejnych biur tego typu rozmieszczonych wzdłuż drugiej pod względem wielkości rzeki kontynentu ${ }^{25}$.

24 Abschlusserklärung der IV. Europäischen Konferenz der Donaustädte und - regionen in Budapest am 11. Juni 2009, www.ulm.de/sixcms/media.php/331/Abschlusserk1\%E4rung.pdf, odczyt z 15 grudnia 2010 r.

25 www.ulm.de/donau_buero_ulm/entstehung_und_entwicklung/entstehung_und_entwicklung.24556.24328,24332,24336.htm, odczyt z 5 stycznia 2011 r. Biura te powstały w: Budapeszcie i Baja (Węgry), Vukovarze (Chrowacja), Nowym Sadzie i Belgradzie (Serbia), Widyniu i Silistrze (Bułgaria) oraz w rumuńskich miejscowościach Orsova, Turnu-Severin, Giurgiu, Galati, Tulcea i Sulina. 
W lutym 2009 r. propozycję z 2002 r. przypomniały członkom Unii dyplomacje austriacka i rumuńska ${ }^{26}$, poparcie wyrazili też wszyscy zainteresowani podczas tzw. Szczytu dunajskiego w Ulm w maju 2009 r. Przychylność wyraziła także, rok wcześniej, komisarz ds. polityki regionalnej Danuta Hübner, apelując o wypracowanie całościowej polityki Brukseli dla tegoż regionu przy uwzględnieniu jego znaczenia dla gospodarki, transportu czy ochrony środowiska ${ }^{27}$. Przywołane przez Hübner argumenty mające przyczyniać się do wzmożenia współpracy pozostawały aktualne. Biorąc pod uwagę m.in. te opinie podczas szczytu Rady Europejskiej w dniach 18-19 czerwca 2009 r. kraje Unii zwróciły się do Komisji o przygotowanie strategii dla analizowanego regionu ${ }^{28}$.

Prace nad opracowaniem unijnej strategii zainaugurowano na spotkaniu w Ulm w dniu 2 lutego 2010 r. zakładając, że ma być ona ukończona jeszcze w tym samym roku. Koordynacją prac zajęła się Komisja Europejska na podstawie rezolucji Parlamentu Europejskiego z 21 stycznia 2010 roku $^{29}$. W dyskusji w Parlamencie ${ }^{30}$ akcentowano m.in. konieczność rozwoju infrastruktury transportowej poprzez modernizację naddunajskich portów i zintegrowanie systemów żeglugi. Gdyby udało się do tego doprowadzić, Europa uzyskała połączenie dróg wodnych Dunaju i Renu wraz z Mozelą, a w konsekwencji połączenie drogą wodną Morza Północnego z Morzem Czarnym, największego portu Unii w Rotterdamie z 10-tym pod względem wielkości w UE portem w Konstancy. Pod względem transportowym nie mniejsze znaczenie miałyby odgrywać szlaki drogowe i kolejowe. Podnoszono też aspekt unikalnego znaczenia przyrody, szczególnie w Delcie Dunaju, której przetrwanie jest uzależnione od stanu wód. W pomyśle dopatrywano się także szansy na niwelowanie różnic w rozwoju unijnych regionów - te położone w Bułgarii czy

26 W tym celu także później odbyło się kilka spotkań z udziałem ministrów spraw zagranicznych obu państw. www.derstandard.at/1242316045606/Oesterreich-und-Rumaenien-fuer-Donaustrategie, odczyt z 14 grudnia 2010 r.

27 A. Szymański, Plany stworzenia strategii UE na rzecz regionu naddunajskiego, „Biuletyn PISM”, nr 45 (577), 30 lipca 2009, s. 2053.

28 Ibidem.

29 „Tygodnik Ośrodka Studiów Wschodnich BEST”, nr 6 (124), 10 lutego 2010, s. 4.

30 Zapis dyskusji na ten temat zob.: www.europarl.europa.eu/sides/getDoc.do?pubRef=-//EP//TEXT+CRE+20100120+ITEM-015+DOC+XML+V0//PL, odczyt z 11 grudnia $2010 \mathrm{r}$. 
Rumunii zaliczają się przecież do najbiedniejszych ${ }^{31}$. Komisarz Olli Rehn zwrócił z kolei uwagę, że strategia powinna opierać się na 3 priorytetach: usprawnieniu systemu łączności przyjaznego dla środowiska, ochronie środowiska oraz wspomaganiu rozwoju zasobów ludzkich i instytucjonalnych.

Prace nad projektem kontynuowano podczas kolejnych konferencji w 2010 r.: w Budapeszcie (luty), Wiedniu i Bratysławie (kwiecień), Ruse (maj) i w Konstancy (czerwiec) ${ }^{32}$. Pewnego rodzaju podsumowaniem prac był Szczyt Dunajski, do którego doszło w Bukareszcie, m.in. w obecności Przewodniczącego Komisji Europejskiej Jose Barroso, 8 listopada 2010 r. Tamże miało miejsce przyjęcie końcowej deklaracji ${ }^{33}$. W niej przedstawiciele rządów 8 państw unijnych: Austrii, Bułgarii, Czech, Niemiec, Słowacji, Słowenii, Rumunii i Węgier z zadowoleniem przyjęli wiadomość o tym, iż prace nad strategią dobiegają końca. Powtórzono znaczenie strategii dla regionu, m.in. dla środowiska i rozbudowy sieci transportowej oraz wyrażono wsparcie dla kooperacji z państwami nie będącymi jeszcze członkami Unii w procesie implementacji europejskich zasad i wartości. Zwrócono też uwagę na konieczność zaproszenia międzynarodowych instytucji finansowych, aby te przyczyniły się poprzez odpowiednie instrumenty finansowe do implementacji planu, zdając sobie jednocześnie sprawę z tego, że konieczne jest lepsze niż do tej pory wykorzystanie unijnych funduszy.

\section{Strategia UE dla regionu Dunaju}

Komisja Europejska przedstawiła wniosek w sprawie Strategii UE dla regionu Dunaju 8 grudnia 2010 roku $^{34}$. Jest to w zasadzie propozycja

31 Ibidem. Odnosząc się do tej problematyki eurodeputowana z Bułgarii Nadezhda Neynsky zwróciła uwagę, że Dunaj ciągle stanowi barierę wręcz nie do pokonania, gdyż na obszarze Bułgarii istnieje tylko jeden most łączący brzegi rzeki, podczas gdy w samym Budapeszcie jest ich aż 9.

32 www.ec.europa.eu/regional_policy/cooperation/danube/events_en.htm, odczyt z 15 grudnia $2010 \mathrm{r}$.

${ }^{33}$ Declaration of the Bucharest Summit on Danube, 8th November 2010, www.ec.europa.eu/regional_policy/cooperation/danube/pdf/bucharest_declaration_ 08112010_en.pdf, odczyt z 12 listopada 2010 r.

34 Strategie der Europäischen Union für den Donauraum, Bruksela, 8 grudnia 2010 r., www.ec.europa.eu, dokument nr $\operatorname{KOM}(2010) 715$. 
stworzenia trzeciego makroregionu w Unii, po makroregionie Morza Bałtyckiego i Morza Śródziemnego. Ma on objąć według planu 14, nie tylko unijnych, krajów takich jak: Austria, Bośnia i Hercegowina, Bułgaria, Chorwacja, Czarnogóra, Czechy, Mołdawia, Niemcy, Rumunia, Serbia, Słowacja, Słowenia, Ukraina i Węgry. W przypadku Niemiec chodzi o 2 kraje związkowe: Bawarię i Badenię-Wirtembergię, w przypadku Ukrainy o 4 obwody: czerniowiecki, iwanofrankowski, odeski, i zakarpacki. Imponująco przedstawia się wielkość obszaru współpracy obejmująca nieco ponad $1,08 \mathrm{mln} \mathrm{km}^{2}$, na której mieszka ponad $115 \mathrm{mln}$ ludzi. Obszar i ludność partnerów mających współpracować w ramach Strategii UE przedstawia tabela 1.

Tabela 1

Obszar i ludność partnerów tworzących Inicjatywę Naddunajską

\begin{tabular}{|l|c|c|}
\hline \multicolumn{1}{|c|}{ Partner } & Powierzchnia $\left(\mathbf{w ~ k m} \mathbf{~}^{\mathbf{}}\right)$ & Ludność (w tys.) \\
\hline Austria & 83871 & 8216,1 \\
\hline Bośnia i Hercegowina & 51197 & 4621,6 \\
\hline Bułgaria & 110879 & 7148,8 \\
\hline Chorwacja & 56594 & 4486,9 \\
\hline Czarnogóra & 13812 & 666,7 \\
\hline Czechy & 78867 & 10201,8 \\
\hline Mołdawia & 33851 & 4317,5 \\
\hline Niemcy & 106301 & 23255,2 \\
\hline Rumunia & 238391 & 21959,3 \\
\hline Serbia & 77474 & 7344,8 \\
\hline Słowacja & 49035 & 5470,3 \\
\hline Słowenia & 20273 & 2003,1 \\
\hline Ukraina & 68084 & 5919,9 \\
\hline Węgry & 93028 & 9992,3 \\
\hline Ogółem: & $\mathbf{1 0 8 1 6 5 7}$ & $\mathbf{1 1 5} \mathbf{6 0 4 , 3}$ \\
\hline \hline
\end{tabular}

Źródło: Opracowanie własne na podstawie: World Factbook, www.cia.gov; Statistisches Bundesamt Deutschland, www.destatis.de; State Statistics Committee of Ukraine, www.ukrstat.gov.ua, odczyty z 26 stycznia 2011 r. W przypadku Niemiec dane dotyczą krajów związkowych Bawaria i Badenia-Wirtembergia, w przypadku Ukrainy obwody: czerniowiecki, iwanofrankowski, odeski i zakarpacki.

Jak podkreślił unijny komisarz ds. rozszerzenia Johannes Hahn zaprezentowana strategia została oparta na ponad 800 opiniach zebranych 
w regonie, którego ma dotyczyć ${ }^{35}$. Świadczy to zatem o dość szerokich konsultacjach społecznych mających spowodować, że pomysł powinien być atrakcyjny dla wszystkich partnerów. Ma wnieść on także ważny wkład w realizację planu Europa 2020, m.in. poprzez spójność różnych unijnych polityk.

Strategia przedstawiona przez Komisję wyszczególnia wyzwania, przed jakimi stoi analizowany region. Zaliczono do nich m.in.:

- niewykorzystaną dotąd mobilność Dunaju jako ważnego korytarza europejskiego TEN-V;

- wysokie koszty energii w regionie wynikające m.in. z małych, rozbitych rynków i słabej na nich konkurencji;

- zanieczyszczenie środowiska naturalnego;

- konieczność wspólnego reagowania w sytuacjach katastrof naturalnych, np. powodzi;

- czynniki społeczne i ekonomiczne - region jest bardzo zróżnicowany jeśli chodzi o dochody społeczeństw i poziom wykształcenia;

- kwestie bezpieczeństwa i ochrony przez zorganizowaną przestępczością ${ }^{36}$.

Dokument przedstawiony 8 grudnia akcentuje szanse stojące przed regionem naddunajskim ${ }^{37}$. Już istniejąca sieć powiązań komunikacyjnych i handlowych pozwala na określenie tej części „brama na Wschód”, nie tylko w kierunku Morza Czarnego, ale także Kaukazu i środkowej Azji. Region dysponuje wprawdzie solidnymi systemami oświatowymi, z licznymi uniwersytetami, choć jakość instytucji kształcących jest zróżnicowana, a w wielu wypadkach pozostawia wiele do życzenia. Obszar objęty strategią cechuje się także różnorodnością etniczną i kulturową, która pozostawiła po sobie m.in. spuściznę architektoniczną mogącą być w przyszłości podstawą rozwoju turystyki. To samo dotyczy bogactw przyrody, wśród których na czoło wysuwają się Karpaty i Delta Dunaju. Wreszcie istnieją możliwości lepszego niż dotąd wykorzystania odnawialnych źródeł energii, co byłoby bez wattpienia mile widziane przez Brukselę przywiązującą do tego elementu dużą wagę.

35 www.europarlament.pap.pl/palio/html.run?_Instance $=$ cms_ep.pap.pl\&_Page$\mathrm{ID}=1 \&$ \&CheckSum $=33470039 \& \_$menuId $=17 \& \_n \mathrm{rDep}=25836$, odczyt 12 grudnia $2010 \mathrm{r}$.

36 Strategie der..., op. cit., s. 3-4.

37 Ibidem, s. 5-6. 
Szczegółowy plan działań w regionie naddunajskim oparty jest na 4 filarach $^{38}$ :

- połączenie regionu, lepsze niż do tej pory, z pozostałą częścią Europy - m.in. poprzez drogi wodne - tu celem jest zwiększenie przewozu towarów Dunajem do roku 2020 o 20\%, drogi kolejowe ${ }^{39}$, wspieranie kultury, turystyki ${ }^{40}$ oraz kontaktów międzyludzkich;

- ochrona środowiska regionu dunajskiego rozumiana jako poprawa stanu wód, zachowanie środowiskowej różnorodności ${ }^{41}$ czy też zarządzanie ryzykiem środowiskowym ${ }^{42}$;

- budowa dobrobytu w regionie poprzez przyczynianie się do rozwoju potencjału badawczego, edukacyjnego ${ }^{43}$ i technologii informacyjnych ${ }^{44}$, a także wspieranie konkurencyjności przedsiębiorstw;

- wzmocnienie regionu naddunajskiego przez poprawę współpracy instytucjonalnej i jej potencjału, kooperację w zwalczaniu zjawiska korupcji i zorganizowanej przestępczości.

Koordynację działań w poszczególnych obszarach przejmą poszczególne państwa objęte strategią. Wyjątkiem będą kwestie objęte już harmonizacją unijna, np. sprawy bezpieczeństwa i zwalczania zorganizowanej przestępczości. Główna rola Komisji Europejskiej będzie polegała na pośredniczeniu, będzie w tym wspierana przez narodowe punkty kontaktowe w każdym z krajów - członków inicjatywy.

Ważną kwestią jest sposób finansowania nakreślonych zadań i ewentualne usytuowanie strukturalne nowej inicjatywy. Strategia Unii Europej-

38 Ibidem, s. 6-12.

39 Celem jest połączenie dróg wodnych, kolejowych i samochodowych w jedną, sprawną sieć do $2020 \mathrm{r}$.

40 Zwrócenie uwagi na Deltę Dunaju jako światowy obszar dziedzictwa przyrody.

41 Np. do 2020 r. ma być zabezpieczona populacja jesiotra dunajskiego zdolna do przeżycia.

42 O potencjalnym zagrożeniu tego typu najlepiej przekonuje katastrofa w węgierskiej hucie aluminium w miejscowości Ajka, gdzie 4 października 2010 r. doszło do wycieku toksycznego szlamu. W jej wyniku zagrożone były dopływy Dunaju, jak również sam Dunaj. Zob.: www.wiadomosci.gazeta.pl/Wiadomosci/1,80708,8464887, Eko_katastrofa_na_Wegrzech_Zabity_i_poparzeni_czerwonym.html, odczyt z 12 października $2010 \mathrm{r}$.

${ }^{43}$ Odniesiono się m.in. do marginalizowanych w kilku krajach regionu społeczności romskich.

44 Do 2013 r. obywatele regionu mają mieć zapewniony dostęp do szerokopasmowego Internetu. 
skiej dla regionu Dunaju nie pozostawia w tym względzie wątpliwości: ,żadnych nowych środków Unii Europejskiej, żadnych nowych przepisów prawnych, żadnych nowych struktur" ${ }^{\text {} 45}$. Dla strategii nie przewiduje się zatem żadnego nowego wsparcia finansowego wychodząc z założenia, że należy się skupić na środkach już dostępnych: w perspektywie finansowej na lata 2007-2013 dla państw, które objęto nową inicjatywą przeznaczono 100 mld euro, poza tym Europejski Bank Inwestycyjny przeznaczył w latach 2007-2009 środki w wysokości 30 mld euro na polepszenie żeglowności i poprawę stanu środowiska naturalnego na analizowanym obszarze. Pewne kwoty są także przeznaczone dla obszaru Bałkanów Zachodnich. Brak nowych środków jest zrozumiały wobec niezakończonego jeszcze, jak się wydaje, kryzysu światowego oraz wobec znaku zapytania, jaki należy obecnie postawić wobec nowej unijnej

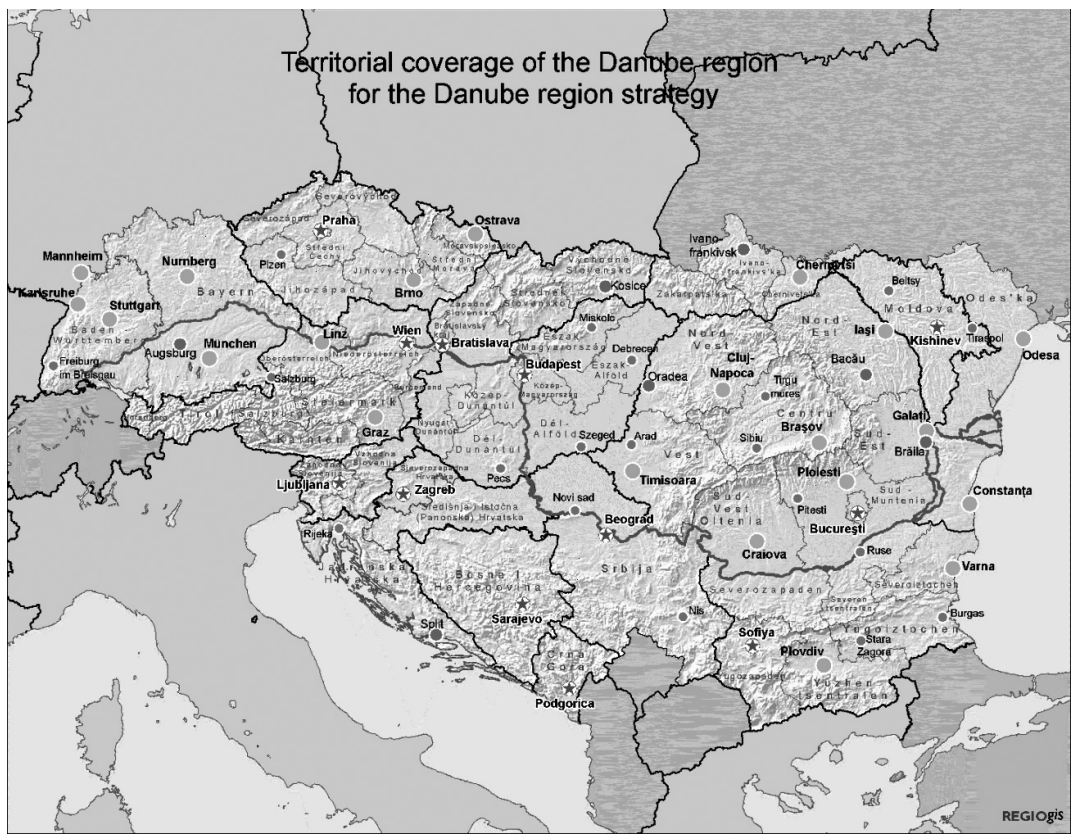

Mapa 1. Obszar współpracy przewidziany w Strategii UE dla obszaru Dunaju Źródlo: www.ec.europa.eu/regional_policy/cooperation/danube/images/danube_topog.png, odczyt z 14 grudnia $2010 \mathrm{r}$.

45 Strategie der..., op. cit., s. 14. 
perspektywy finansowej na lata 2014-2020. Może się bowiem okazać, że środki do dyspozycji nie będą większe od obecnych. Zapewne nie pozostałoby to bez wpływu na realizację Strategii.

Uzupełnieniem planu z 8 grudnia był podział zadań koordynacyjnych dotyczących poszczególnych obszarów. Przedstawili go 3 lutego $2011 \mathrm{r}$. komisarz Hahn i węgierski minister spraw zagranicznych János Martonyi ${ }^{46}$. Zadaniem poszczególnych państw będzie koordynowanie prac w danych zakresach tematycznych poprzez uzgodnienia z pozostałymi partnerami projektu oraz organizacjami pozarządowymi, wypracowywanie programów roboczych i wyszukiwanie ich źródeł finansowania. Każdy z partnerów odpowiada za co najmniej jeden zakres tematyczny, np. Węgry i Czechy za wsparcie w wykorzystywaniu odnawialnych źródeł energii, Austria i Mołdawia za inwestowanie w ludzi i ich kwalifikacje, Węgry i Rumunia za zarządzanie ryzykiem środowiskowym a Badenia-Wirtembergia wspólnie z Chorwacją za wsparcie konkurencyjności przedsiębiorstw ${ }^{47}$. Specjalnych zadań nie otrzymały jedynie Czarnogóra oraz Bośnia i Hercegowina choć zaznaczono, że w razie potrzeby także one zostaną wciagnięte $\mathrm{w}$ prace koordynacyjne pozostając pełnoprawnymi członkami strategii.

Kraje członkowskie Unii wsparły ostatecznie pomysł podczas spotkania Rady ds. Ogólnych Rady UE w dniu 13 kwietnia 2011 roku. Nieprzypadkowo nastapiło to podczas węgierskiej Prezydencji w Radzie - wszak państwo to jest jednym z najbardziej zainteresowanych nowym pomysłem regionalnej kooperacji. Po objęciu przewodnictwa w Radzie Unii Europejskiej przez Węgry 1 stycznia 2011 roku kwestia strategii Brukseli wobec regionu naddunajskiego nie znalazła się wśród priorytetów przewodnictwa. Mimo to - jak akcentował premier Viktor Orban - sprawa ta znalazła się wśród istotnych problemów, którym Budapeszt chciał poświęcić nieco więcej miejsca ${ }^{48}$. Doczekała się ona finalizacji co jest niewątpliwie pewnym sukcesem Węgier.

46 EU-Strategie für den Donauraum: Kommissar Hahn gibt Koordinatoren für die Schwerpuktbereiche bekannt, www.europa.eu/rapid/pressReleasesAction.do?reference $=\mathrm{IP} / 11 / 124 \&$ format $=$ HTML\&aged $=0$ \&language $=$ EN\&guiLanguage $=e n$, od czyt z 7 lutego 2011 r., Dokument nr IP/11/124, Bruksela, 3 lutego 2011 r.

47 Ibidem, zob. załącznik do dokumentu.

48 Wegry już oficjalnie przewodza w UE, www.tvp.info/informacje/swiat/wegry-przejmuja-przewodnictwo-w-ue/3746752, odczyt z 10 stycznia $2011 \mathrm{r}$. 
W dokumencie przyjętym 13 kwietnia - otwierającym drogę do realizacji strategii - podkreślono główną, koordynującą rolę Komisji Europejskiej we wdrażaniu koncepcji. Pierwsza ocena procesu implementacji strategii ma ukazać się najpóźniej do końca 2012 roku $^{49}$.

Zamierzenia przedstawione w strategii z 8 grudnia należy ocenić jako ambitne choć warto od razu postawić pytanie czy możliwe do zrealizowania? Kanclerz Niemiec Angela Merkel już w marcu 2010 r. zwracała uwagę, że główne wytyczne programu mogą być z sobą trudne do pogodzenia $^{50}$. Jak bowiem połączyć konieczność szybkiego rozwoju gospodarczego - niezbędnego warunku dla wzrostu dobrobytu społecznego - w krajach zapóźnionych gospodarczo (np. w Bośni i Hercegowinie, Bułgarii czy na Ukrainie) z koniecznością poprawy stanu środowiska? Jak połączyć plany zwiększenia przewozu towarów rzeką z chęcią zachowania różnorodności gatunków ryb w tej samej rzece? Realizacja tych planów może się okazać bardzo trudna lub wręcz niemożliwa. $\mathrm{Z}$ pewnością nie jest możliwa bez kosztownych inwestycji.

Ideałem byłoby zrealizowanie przynajmniej części zadań przedstawionych przez Komisję Europejską. Zapewne minie przynajmniej kilka lat by można było obiektywnie ocenić jak strategia jest wdrażana i jakie konkretnie przynosi efekty. Ważne będą nie tylko działania podejmowane na szczeblu wspólnotowym, ale przede wszystkim wdrożenie ich w praktyce na szczeblu regionalnym i lokalnym. Inicjatywa Brukseli w tym zakresie może też oznaczać wzrost znaczenia podejścia makroregionalnego w samej Unii: region dunajski może stać się trzecim ważnym obszarem UE po regionach M. Śródziemnego i M. Bałtyckiego.

Trudno zgodzić się z opinią, iż realizacja Inicjatywy Naddunajskiej „może osłabić znaczenie Partnerstwa Wschodniego jako istotnego forum realizacji polityki wschodniej UE" ${ }^{\text {"51 }}$. Co najwyżej na pewnym obszarze mogą się one pokrywać odnosząc się do tych samych państw. Z punktu widzenia Polski Partnerstwo Wschodnie jest ważniejsze, ale z punktu widzenia takich państw jak Austria czy Węgry jest dokładnie odwrotnie. Nie oznacza to, że droga do wdrożenia strategii będzie łatwa.

49 Council conclusions on the European Union Strategy for the Danube Region, Bruksela, 13 kwietnia 2011 r., www.consilium.europa.eu/uedocs/cms_data/docs/pressdata/EN/genaff/121511.pdf, odczyt z 16 kwietnia $2011 \mathrm{r}$.

50 www.euractiv.de/regionalpolitik/artikel/vier-leitlinien-fr-die-donauregion-003926, odczyt 15 listopada 2010 r.

${ }^{51}$ A. Szymański, op. cit., s. 2054. 
Wśród potencjalnych problemów związanych z jej realizacją należy wymienić:

- kłopoty wewnętrzne poszczególnych państw;

- trudności w określeniu przyszłości polityki zewnętrznej Ukrainy pod rządami prezydenta Janukowycza;

- problem rozwoju Bośni i Hercegowiny zarówno w obliczu współpracy w regionie naddunajskim, jak i w ewentualnych staraniach o członkostwo w UE;

- nastawienie społeczeństw krajów członkowskich do dalszego rozszerzania Wspólnoty Europejskiej, w tym w szczególności społeczeństwa austriackiego;

- kwestię napiętych stosunków między Węgrami a krajami sąsiednimi (Rumunia, Serbia, Słowacja), odnośnie do licznych grup mniejszości narodowych w tych krajach;

- rozwój gospodarczy unijnych krajów regionu, zwłaszcza Bułgarii i Rumunii, które widocznie odstają od średniej unijnej, jeśli chodzi o zamożność;

- problem korupcji, która jak dotąd nie została zwalczona w tym regionie, mimo zapowiedzi Brukseli, i to nie tylko wśród krajów pozaunijnych, ale i np. w Bułgarii.

Potencjalnych kłopotów zatem nie brakuje. Zapobieżenie im, względnie ich pokonanie, będzie warunkiem niezbędnym dla powodzenia całego projektu.

\section{Podsumowanie}

Strategia UE dla regionu Dunaju weszła w życie w 13 kwietnia 2011 $\mathrm{roku}^{52}$. Pozytywnym aspektem propozycji przedstawionej przez Komisję Europejską 8 grudnia 2010 r. i wprowadzonej kilka miesięcy później w życie jest wciągnięcie do współpracy regionalnej państw znajdujących się w tym momencie poza Unią: Bośni i Hercegowiny, Czarnogóry, Mołdawii, Serbii, Ukrainy i Chorwacji. Negocjacje akcesyjne z tą ostatnią dobiegają końca ${ }^{53}$. Być może poprzez zaangażowanie w tę propozycję Brukseli pozwoli na ich przybliżenie do unijnych struktur, a przede wszystkim okaże się korzystne dla rozwoju społeczeństw tych krajów.

52 Artykuł oddaje stan wiedzy autora na dzień 20 kwietnia $2011 \mathrm{r}$.

$53 \mathrm{Na}$ koniec $2010 \mathrm{r}$. w toku rozmów negocjacyjnych z Chorwacją zamknięto 25 z 35 rozdziałów, w których toczą się rozmowy. Zob.: www.ec.europa.eu/enlargement/press_corner/whatsnew/croatia_en.htm, odczyt z 1 lutego 2011 r. 
Na szczęście - odnosząc się do pytania postawionego w tytule artykułu - nie jest to nowy plan Tardieu. Obecna propozycja, w przeciwieństwie do oferty z początku lat 30-tych XX stulecia, nie jest planem narzuconym z zewnątrz, lecz pomysłem opierającym się na analizie potrzeb regionu. Jest planem wspólnotowym przedstawionym w zupełnie odmiennej sytuacji niż prawie 80 lat temu. Tak wtedy jak i dziś część państw analizowanego rejonu Europy poważnie odstaje od bogatszej, zachodniej części kontynentu, pod względem ekonomicznego rozwoju.

Czas pokaże czy inicjatywa ta jest w ogóle potrzebna i czy przynosi efekty. Dziś można bowiem zadać pytanie czy planowanych zadań nie można było wprowadzać w życie bez ogłaszania specjalnej strategii dla całego makroregionu. Tym bardziej, że nie wiąże się ona z żadnymi dodatkowymi funduszami, a tylko z planami lepszego wykorzystania już istniejących.

Zadania nakreślone w strategii są niełatwe w praktycznej realizacji, zważywszy szczególnie na problemy, jakie miały miejsce na Bałkanach w ostatnich 20 latach. Jednakże tylko podjęcie zadań ambitnych i, na pierwszy rzut oka, trudnych w urzeczywistnieniu, może doprowadzić do tego, aby region naddunajski, a w szczególności jego południowo-wschodnia część, stały się regionem XXI wieku - o czym Strategia UE także wspomina. W strategii mowa jest o roku 2020 jako dacie ewentualnych zauważalnych zmian. Czas pokaże czy tak się stanie.

\section{The European Union's initiative for the Danube region. A new Tardieu Plan?}

\section{Summary}

The new EU Strategy for the Danube Region came into force on April 13, 2011. Referred to as the Danube Initiative it assumes cooperation within a greater European macro-region covering $1,080,000 \mathrm{~km}^{2}$ with over $115,000,000$ inhabitants. The region encompasses as many as fourteen states, six of which are currently outside the European Union. Brussels aims to develop an improved transportation network inside the region by means of water, rail and roads, achieve stronger commitment to environmental protection, contribute to increased prosperity in this part of Europe and improve institutional cooperation in order to fight corruption and organized crime. Achieving these challenging goals is to result in increased unification of the region, in particular its less developed territories, with the UE in terms of economy and social development. The implementation of the Danube Initiative does not involve the establishment of any new institutions or resources. The goals are to be achieved by making better use of current measures. 